\title{
Penerapan Kran Otomatis Guna Pencegahan Covid-19 untuk Masjid Jami Al-Istiqomah di Kelurahan Setrojenar, Kecamatan Buluspesantren, Kabupaten Kebumen
}

\section{Asni Tafrikhatin}

Program Studi Teknik Elektronika, Politeknik Dharma Patria, Indonesia, 54311

E-mail: asnitafrikhatin@gmail.com

DOI: https://doi.org/10.37339/jurpikat.v1i2.306

\section{Info Artikel: \\ Diterima : \\ 2020-10-12 \\ Diperbaiki : \\ 2020-10-18}

Disetujui :

2020-10-24

Kata kunci: Covid-19, Cuci Tangan, Kran Otomatis

\begin{abstract}
Abstrak: Penularan Covid-19 sangat cepat karena penularannya melalui droplets atau percikan batuk/bersin. Penularan yang sangat mudah mengakibatkan jumalh warga yang terkana Covid-19 meningkat tajam. Pemerintah saat ini mulai menerapkan adaptasi kebiasaan baru. Kegiatan yang harus dilakukan untuk pencegahan Covid-19 adalah memakai masker, mencuci tangan dan menjaga jarak. Pemerintah juga sudah mengijinkan warga untuk melaksanakan ibadah di tempat ibadah. Masjid Jami'Al-Istiqomah merupakan salah satu tempat ibadah yang terletak di Kelurahan Setrojenar, Kecamatan Buluspesantren, Kabupaten Kebumen. Masjid Jami' Al-Istiqomah menyediakan fasilitas cuci tangan, namun fasilitas tersebut belum memadai. Tujuan pengabdian ini adalah untuk meningkatkan kesadaran mencuci tangan. Metode pengabdian yaitu survey, studiliteratur, dan eksperimen. Tahapan pengabdian yaitu: observasi, pembuatan alat, penyerahan alat, perhitungan pengguna, dan evaluasi. Hasil pengabdian berupa kran otomatis yang diletakkan di Masjid Jami' Al-Istiqomah. Kran otomatis tersebut menarik perhatian jamaah untuk mencuci tangan. Harapannya masyarakat Kelurahan Setrojenar terhindar dari Covid-19.
\end{abstract}

Abstract: Covid-19 transmission is very fast because it is transmitted through droplets or coughing/sneezing. 
Keywords: Covid-19, Washing Hands, Automatic Faucet
Transmission is very easy, resulting in the number of people infected with Covid-19 to increase sharply. The government is currently starting to adopt new habitual adaptations. Activities that must be done to prevent Covid19 are wearing masks, washing hands and maintaining distance. The government has also allowed residents to worship in places of worship. Jami' Al-Istiqomah's Mosque is one of the places of worship located in Setrojenar, Buluspesantren, Kebumen. Jami 'Al-Istiqomah's Mosque provides hand washing facilities, but these facilities are not maximally. The purpose of this service is to improve awareness of washing hands. The service methods are survey, literature study, and experiment. The service stages are: observation, making tools, handing over tools, calculating users, and evaluating. The service resulted in the form of an automatic faucet that was placed in the Jami 'Al-Istiqomah Mosque. The automatic faucet attracts the attention of the congregation to wash their hands. The hope is that the people of Setrojenar will be protected from Covid19.

\section{Pendahuluan}

Saat ini, telah terjadi pandemi Covid-19. Pandemi Covid-19 dapat terjadi karena penularan Covid-19 yang sangat cepat. Pertama kali Covid-19 ditemukan di Wuhan, China pada tanggal 31 Desember 2019 (Yuliana, 2020). Penularan Covid-19 melalui droplets atau percikan batuk/bersin (Susilo et al., 2020). Selain itu, penyebaran virus corona dapat secara tidak langsung. Penyebaran tersebut melalui benda-benda yang tercemar virus akibat percikan atau sentuhan tangan yang tercemar virus. khir Januari 2020 WHO menetapkan status Global Emergency pada kasus virus Corona ini dan pada 11 Februari 2020 WHO menamakannya sebagai COVID-19 (D. Handayani et al., 2020). Oleh karena itu, pemerintahan Indonesia menyuruh semua Pemprov melakukan analisis jumlah warga yang terkena Covid-19.

Salah satu Provinsi di Indonesia yang giat melaporkan hasil penelusuran penyebaran Covid-19 adalah Pemprov Jawa Tegah. Pemprov Jawa Tengah merupakan salah satu provinsi yang memiliki jumlah penduduk yang cukup banyak di Indonesia, sehingga Pemprov menyarankan setiap kabupaten untuk membuat website tentang penelusuran penyebaran Covid-19. Kabupaten Kebumen merupakan salah satu kabupaten yang terletak di Provinsi Jawa Tengah. Berdasarkan rilis peta zonasi Covid-19 yang dikeluarkan oleh Pemprov Jawa Tengah per 1 Oktober 2020, 
Kabupaten Kebumen masuk ke dalam zona orange (Tim BNPB Kebumen, 2020). Peta zonasi Covid-19 yang dikeluarkan Pemprov Jawa Tengah disajikan pada Gambar 1.

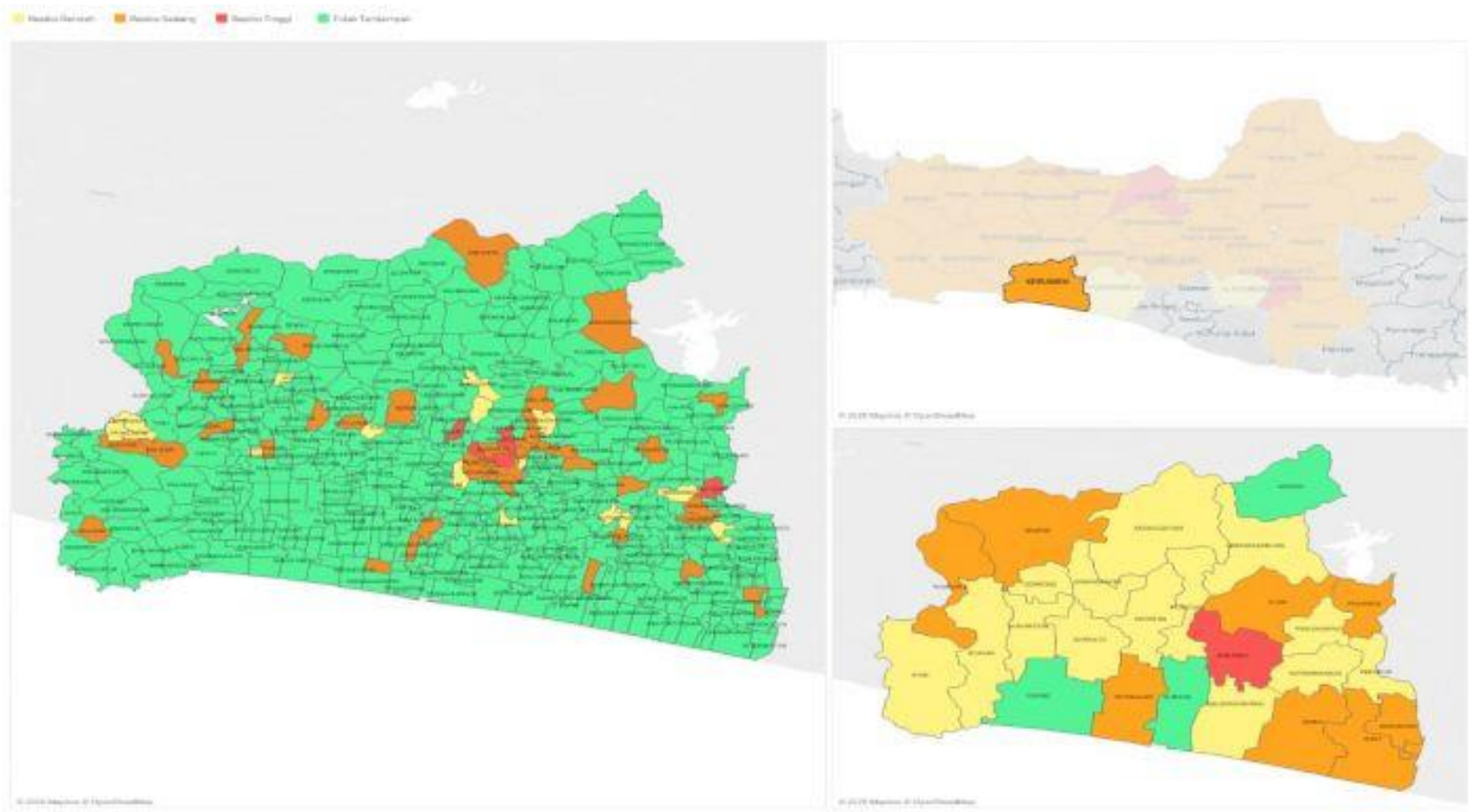

Gambar 1. Peta Zonasi Covid-19 Pemprov Jawa Tengah

(Tim BNPB Kebumen, 2020)

Kabupaten Kebumen dinyatakan sebagai zona orange karena hamper semua kecamatan di Kabupaten Kebumen berzona orange. Berdasarkan data pada tanggal 17 Oktober 2020, warga kebumen yang terkonfirmasi terkena Covid-19 sejumlah 1.077 orang, sedangkan yang masih menjalani perawatan untuk penyembuhan Covid-19 sejumlah 86 orang.

Pemerintah Kabupaten Kebumen selalu berusaha untuk menekan jumlah warga yang terkonfirmasi Covid-19. Salah satu upaya dari pemerintah Kabupaten Kebumen adalah melakukan tracing bagi warga yang terkonfirmasi positif. Setiap puskesmas wajib membantu Dinas Kesehatan Kabupaten Kebumen untuk melakukan tracing kepada warga yang terkonfirmasi positif di wilayah kecamatannya. Berdasarkan data pada tanggal 17 Oktober 2020, data persebaran warga kebumen yang positif terkena Covid-19 pada setiap wilayah kecamatan yang terdapat di Kebumen dapat dilihat pada Tabel 1. 
Tabel 1. Persebaran Warga Kebumen yang Positif Covid-19

(Update: 9 Oktober 2020)

\begin{tabular}{|c|c|c|c|c|c|}
\hline \multirow{2}{*}{ No. } & \multirow{2}{*}{ Kecamatan } & \multicolumn{4}{|c|}{ Positif } \\
\hline & & Meninggal & Dirawat & Sembuh & Total \\
\hline 1 & Ayah & 1 & 1 & 13 & 15 \\
\hline 2 & Buayan & 0 & 1 & 11 & 12 \\
\hline 3 & Puring & 1 & 10 & 20 & 31 \\
\hline 4 & Petanahan & 1 & 5 & 15 & 21 \\
\hline 5 & Klirong & 0 & 3 & 13 & 16 \\
\hline 6 & Buluspesantren & 0 & 6 & 13 & 19 \\
\hline 7 & Ambal & 1 & 2 & 12 & 15 \\
\hline 8 & Mirit & 0 & 9 & 10 & 19 \\
\hline 9 & Prembun & 0 & 6 & 29 & 35 \\
\hline 10 & Kutowinangun & 1 & 5 & 24 & 30 \\
\hline 11 & Alian & 2 & 67 & 36 & 105 \\
\hline 12 & Kebumen & 12 & 109 & 272 & 393 \\
\hline 13 & Pejagoan & 2 & 10 & 11 & 23 \\
\hline 14 & Sruweng & 1 & 7 & 21 & 29 \\
\hline 15 & Adimulyo & 0 & 1 & 8 & 9 \\
\hline 16 & Kuwarasan & 0 & 2 & 4 & 6 \\
\hline 17 & Rowokele & 1 & 1 & 42 & 44 \\
\hline 18 & Sempor & 0 & 4 & 4 & 8 \\
\hline 19 & Gombong & 0 & 5 & 17 & 22 \\
\hline 20 & Karanganyar & 0 & 4 & 9 & 13 \\
\hline 21 & Karanggayam & 0 & 3 & 4 & 7 \\
\hline 22 & Sadang & 0 & 0 & 1 & 1 \\
\hline 23 & Bonorowo & 0 & 1 & 11 & 12 \\
\hline 24 & Padureso & 0 & 3 & 1 & 4 \\
\hline 25 & Poncowarno & 0 & 1 & 2 & 3 \\
\hline 26 & Karangsambung & 0 & 7 & 9 & 16 \\
\hline
\end{tabular}

(Tim BNPB Kebumen, 2020)

Berdasarkan Tabel 1, kecamatan Kebumen merupakan kecamatan terbanyak yang warganya terkena Covid-19, sedangkan Kecamatan Sadang merupakan kecamatan yang paling sedikit warganya terkena Covid-19.

Kecamatan Buluspesantren merupakan salah satu kecamatan yang terletak di Kabupaten Kebumen. Berdsarkan Tabel 1, warga Kecamatan Buluspesantren terdapat 
19 orang yang positif terkena Covid-19. Kecamatan Buluspesantren memang tidak terlalu banyak warganya yang terkena Covid-19, namun warga kecamatan Buluspesantren tetap dihimbau untuk menerapkan memakai masker, mencuci tangan, dan menjaga jarak.

Penyakit ini masih belum ditemukan obat maupun vaksinnya, padahal pandemic Covid-19 sudah lebih setengah tahun (Farizi et al., 2020). Hal ini menyebabkan pemerintah mencanangkan adaptasi kebiasaan baru dengan berdamai dengan Covid-19. Adaptasi kebiasaan baru (new normal) adalah suatu tindakan atau perilaku yang dilakukan masyarakat dan semua institusi yang ada di wilayah tersebut untuk melakukan pola harian atau pola kerja atau pola hidup yang berbeda dengan sebelumnya (Beniac et al., 2006). Tujuan dari adaptasi kebiasaan baru adalah agar masyarakat tetap produktif dan aman dari Covid-19 (R. T. Handayani et al., 2020).

Masyarakat Kebumen sudah diperbolehkan untuk melakukan kegiatan ibadah di masjid (Pencegahan Penularan Corona Virus Diseases (Covid-19) 2019 Di Kabupaten Kebumen, 2020). Saat melakukan ibadah, Pemerintah Kabupaten Kebumen selalu mengimbau kepada masyarakat untuk menerapkan 3M (memakai masker, mencuci tangan, dan menjaga jarak). Berbagai upaya masyarakat lakukan untuk tetap melakukan 3M. Masyarakat di Indonesia melakukan berbagai temuan seperti: kran otomatis berbasis Arduino menggunakan sensor PIR (Latuconsina et al., 2017), sensor hc-04 (Hartanto \& Fitriyanto, 2019), ataupun sensor ultrasonik (Shaputra et al., 2019). Walaupun sensor yang digunakan itu berbeda-beda, namun pada dasarnya mendeteksi ada dan tidaknya suatu benda di depan sensor serta pengaturan jarak deteksi antara sensor dengan bendanya.

Sensor proximity ada berbagai macam diantaranya sensor proximity induksi, sensor proximity kapasitif, dan sensor proximity optic (Susilawati et al., 2017). Sensor proximity induksi merupakan sensor yang mendeteksi bahan logam (Susilawati et al., 2017). Sensor proximity kapasitif merupakan sensor yang mendeteksi logam maupun non logam (Bahtiar et al., 2019). Sensor proximity optic merupakan sensor yang mendeteksi benda apapun yang dapat dipantulkan oleh infrared. Sensor proximity pada dasarnya merupakan sensor jarak. Pengaturan jarak pada sensor proximity cukup mudah yaitu dengan memutar head timer yang ada di belakang sensor. Pemilihan sensor yang akan digunakan harus disesuaikan dengan kebutuhan.

Masjid Jami' Istiqomah yang terletak di Kelurahan Setrojenar Kecamatan Buluspesantren Kabupaten Kebumen merupakan salah satu tempat ibadah yang sudah aktif. Masyarakat sekitar Masjid Jami'Istiqomah sudah melaksanakan kegiatan rutin sholat wajib berjamaah, pengajian ahad manis, dan kegiatan TPQ setiap habis 
magrib. Pemerintah Kabupaten Kebumen menghimbau untuk tempat ibadah diberi fasilitas cuci tangan. Walaupun Sebagian besar orang yang akan pergi ke masjid selalu dalam keadaan berwudhu, namun sebulum berwudhu, Sebagian warga tidak mencuci tangan menggunakan sabun terlebih dahulu. Oleh karena itu, Ta'mir Masid Jami' Al-Istiqomah memberikan fasilitas untuk mencuci tangan. Kondisi alat cuci tangan di Masjid Jami' Al-Istiqomah disajikan pada Gambar 2.

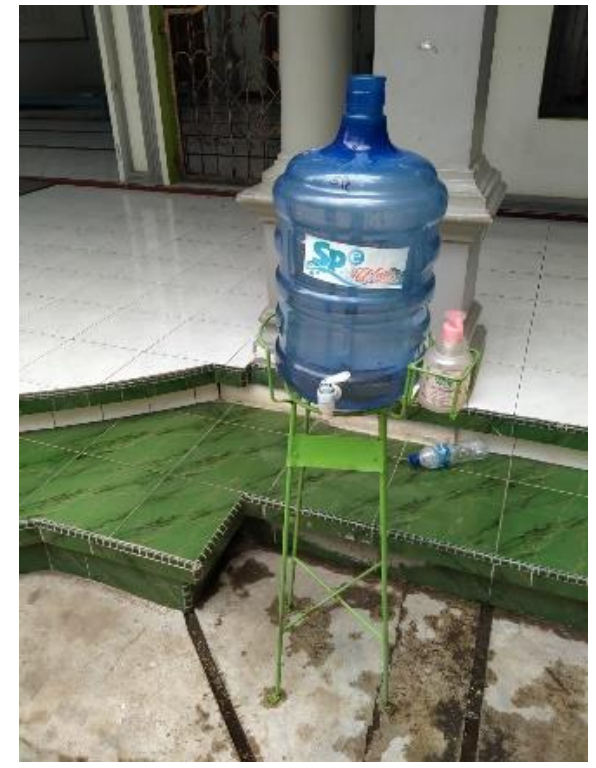

Gambar 2. Kondisi Alat Cuci Tangan Masjid Jami' Al-Istiqomah

Berdasarkan Gambar 2, fasilitas cuci tangan di Masjid Jami'Al-Istiqomah masih menggunakan kran manual, sehingga pencegahan Covid-19 kurang maksimal. Selain itu, fasilitas cuci tangan tersebut kurang diminati warga. Oleh karena itu, fasilitas cuci tangan tersebut harus diberi inovasi agar jamaah Masjid Al-Istiqomah dapat lebih tertarik untuk menucui tangan menggunakan sabun sebelum masuk masjid. Pengabdian masyarakat ini merupakan pembuatan kran otomatis untuk fasilitas cuci tangan di Masjid Jami' Al-Istiqomah.

\section{Metode}

Pengabdian masyarakat ini dilaksanakan di Masjid Jami'Al-Istiqomah yang terletak di Kelurahan Setrojenar, Kecamatan Buluspesantren, Kabupaten Kebumen, Propinsi Jawa Tengah. Pelaksanaan pengabdian masyarakat dimulai pada tanggal 23 Agustus sampai 9 September 2020. Subjek pengabdian masyarakat ini adalah jamaah Masjid Jami' Al-Istiqomah. Metode penelitian ini adalah obseravasi, studi literatur, dan eksperimen. Tahapan-tahapan pengabdian masyarakat disajikan pada Gambar 3. 


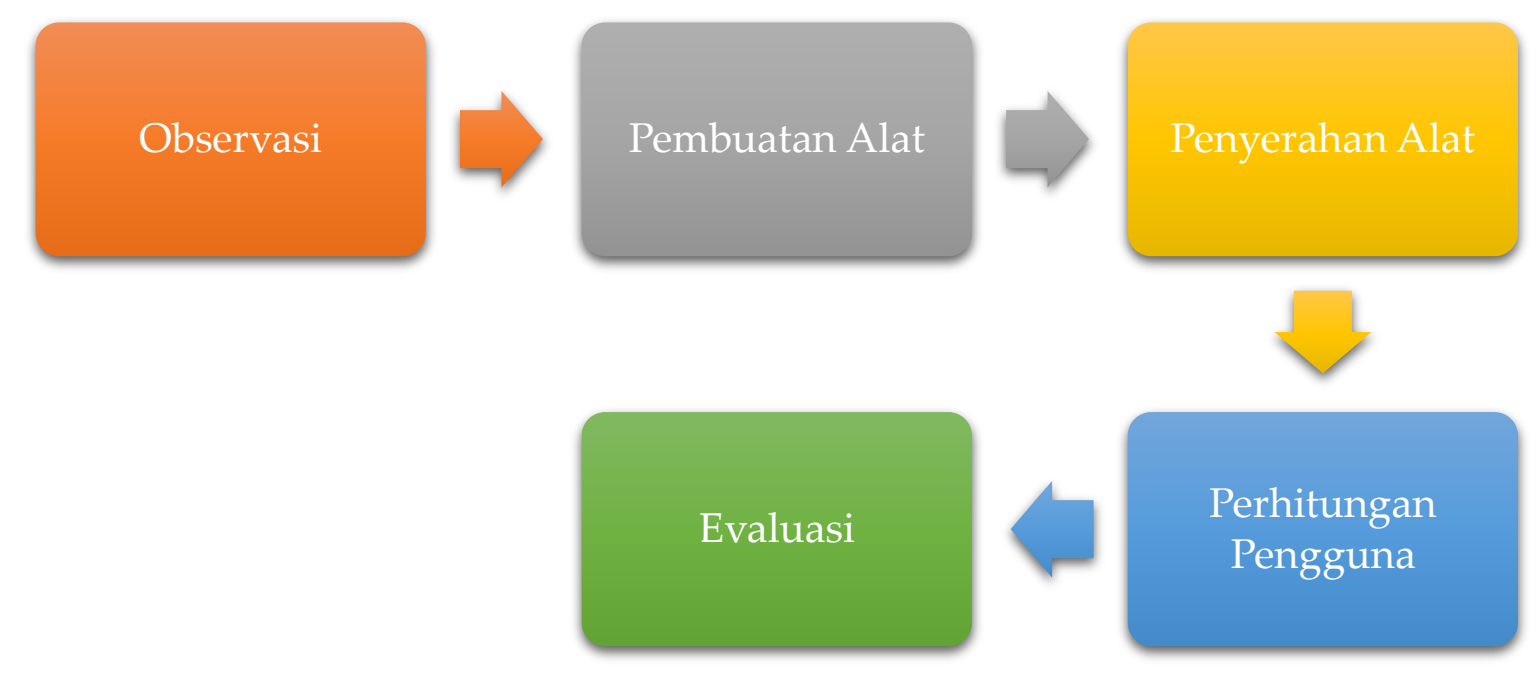

Gambar 3. Tahapan Pengabdian Masyarakat

Tahapan pertama adalah observasi. Observasi dilakukan oleh kami ketika ada salah satu jamaah yang mengeluh dengan peningkatan jumlah warga kebumen yang terkena Covid-19. Kami melakukan observasi permasalahan 3M (memakai masker, mencuci tangan, dan menjaga jarak). Observasi dilaksanakan selama 7 hari mulai dari tanggal 23 sampai 29 Agustus 2020.

Tahap kedua adalah pembuatan alat sesuai dengan penemuan permasalahan di masyarakat Ketika melakukan observasi. Pembuatan alat ini dengan mengembangkan peralatan yang ada. Tahap ketiga adalah penyerahan alat yang telah dikembangkan. Penyerahan alat tersebut kepada perwakilan dari Ta'mir Masjid Jami' Al-Istiqomah. Penyerahan alat dilakukan secara informal karena kami ingin mengetahui dampak dari dipasangnya alat yang dikembangkan.

Tahap keempat adalah perhitungan pengguna alat yang dikembangkan tersebut. Perhitungan jumlah jamaah yang menggunakan alat tersebut dilakukan selama 7 hari yaitu tanggal 1 sampai 7 September 2020. Tahap terakhir adalah evaluasi. Tahap evaluasi ini adalah membandingkan jumlah pengguna saat sebelum dan setelah diberi alat yang kami kembangkan. Berdasarkan uraian di atas dapat digambarkan grafik waktu pelaksanaan pengabdian masyarakat yang disajikan pada Tabel 2. 
Tabel 2. Jadwal Kegiatan Pengabdian Masyarakat

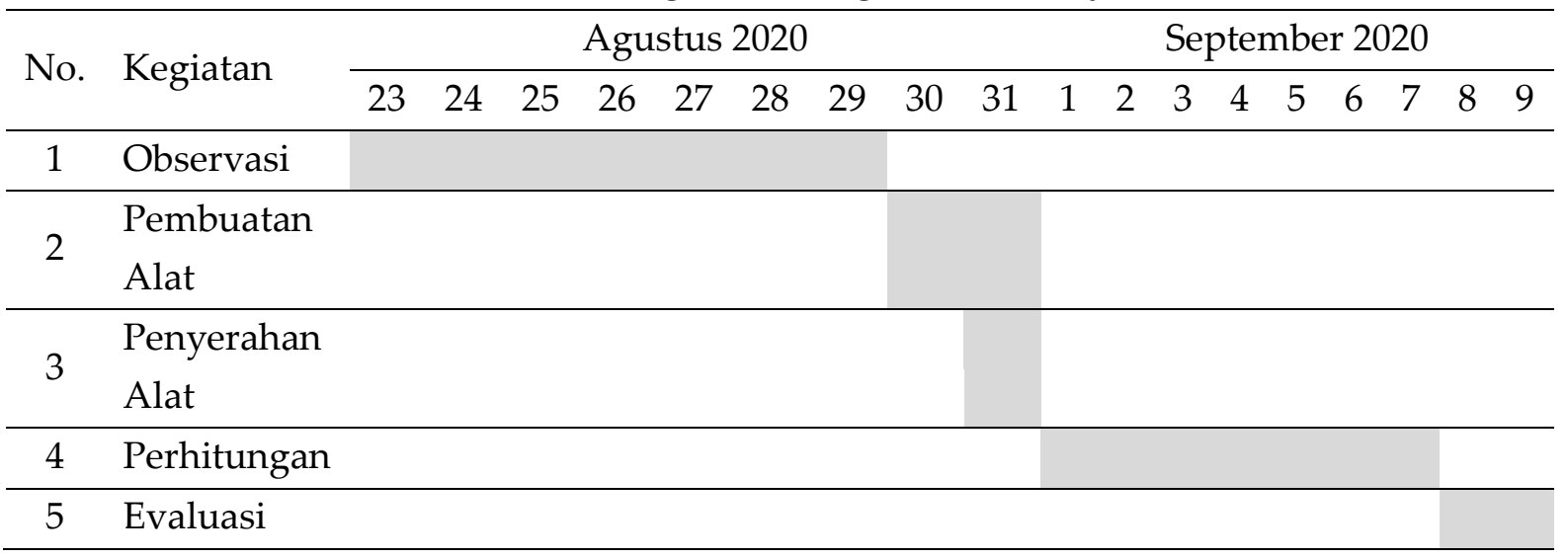

\section{Hasil dan Pembahasan}

Hasil dari pengabdian msyarakat adalah sebagai berikut.

\section{Observasi}

Observasi dilakukan selama 7 hari berturut-turut dengan cara mengamati secara sembunyi-sembunyi berapa jumlah jamaah yang menggunakan fasilitas cuci tangan sebelum masuk masjid. Hasil pengamatan diambil saat sholat magrib karena jumlah jamaah terbanyak pada saat sholat magrib. Hasil data pengamatan disajikan pada Tabel 3.

Tabel 3. Pengguna Fasilitas Cuci Tangan di Masjid Jami' Al-Istiqomah

\begin{tabular}{ccc}
\hline No. & Hari ke- & Jumlah warga \\
\hline 1. & 1 & 5 \\
\hline 2. & 2 & 4 \\
\hline 3. & 3 & 5 \\
\hline 4. & 4 & 3 \\
\hline 5. & 5 & 5 \\
\hline 6. & 6 & 6 \\
\hline 7. & 7 & 6 \\
\hline
\end{tabular}

2. Pembuatan Alat

Kran otomatis yang akan dibuat untuk fasilitas cuci tangan di Masjid Jami' AlIstiqomah adalah kran yang dilengkapi dengan sensor proximity (sensor jarak) sehingga ketika ada benda yang ada di depan sensor maka sensor akan mengirimkan sinyal dalam bentuk tegangan positif yang akan digunakan untuk memicu rangkaian kontrol untuk pompa air dan rangkaian kontrol untuk solenoid valve. 
Suplay daya listrik kran otomatis menggunkan catu daya arus searah (DC) agar lebih aman. Sistem kelistrikan untuk kran otomatis dibuat seaman mungkin. Kran otomatis ini sumbernya berupa baterai yang dapat di isi ulang. Bentuk fisik kran otomatis disajikan pada Gambar 4.

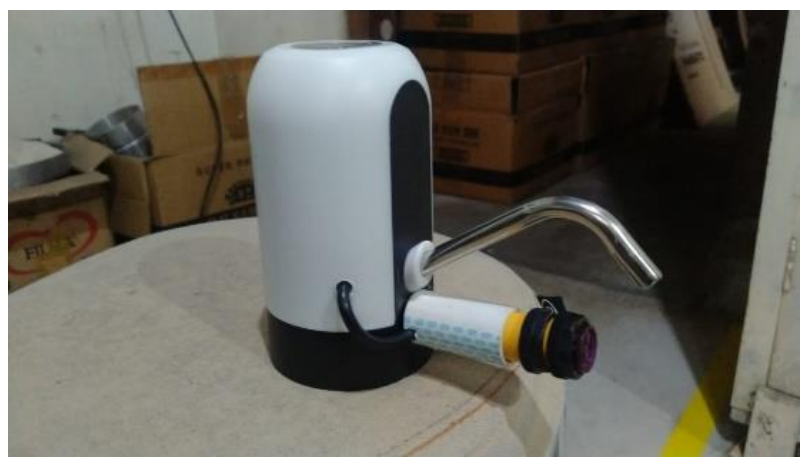

Gambar 4. Bentuk Fisik Kran Otomatis

Bahan-bahan yang dibutuhkan untuk pembuatan alat ini adalah pompa gallon elektrik dan sensor proximity E18-D80NK. Langkah-langkah pembuatannya adalah (1) membuka pompa gallon elektrik, (2) memasang kabel proximity yang berwarna coklat ke VCC dan kabel biru ke ground, (3) memasang kabel proximity yang berwarna hitam ke basis pada transistor PNP yang ada dalam pompa elektrik gallon. Pengaturan jarak pada sensor proximity terletak di belakang sensor. Jarak yang dapat mendeteksi sensor ini adalah 3 sampai $80 \mathrm{~cm}$. Gambar rangkaian dari kran otomatis disajikan pada Gambar 5.

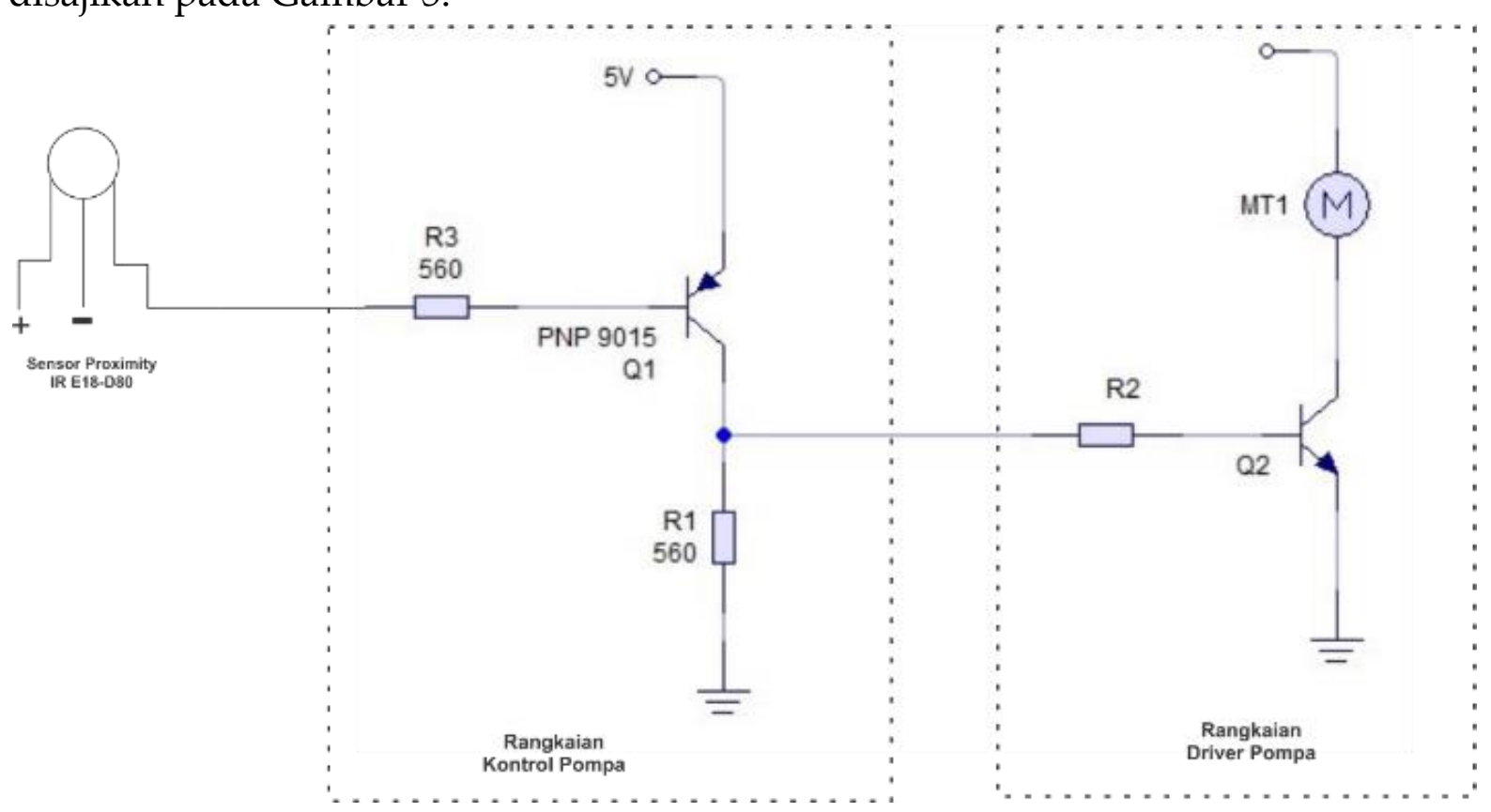

Gambar 5. Rangkaian Kran Otomatis 


\section{Penyerahan Alat}

Penyerahan kran otomatis diserahkan kepada perwakilan Ta'mir Masjid Jami' Al-Istiqomah. Pihak Ta'mir cukup terbantu dengan adanya kran otomatis. Harapan dari pihak Ta'mir, kran otomatis ini dapat meningkatkan kesadaran masyarakat Kelurahan Setrojenar untuk selalu mencuci tangan. Gambar penyerahan kran otomatis disajikan pada Gambar 6.

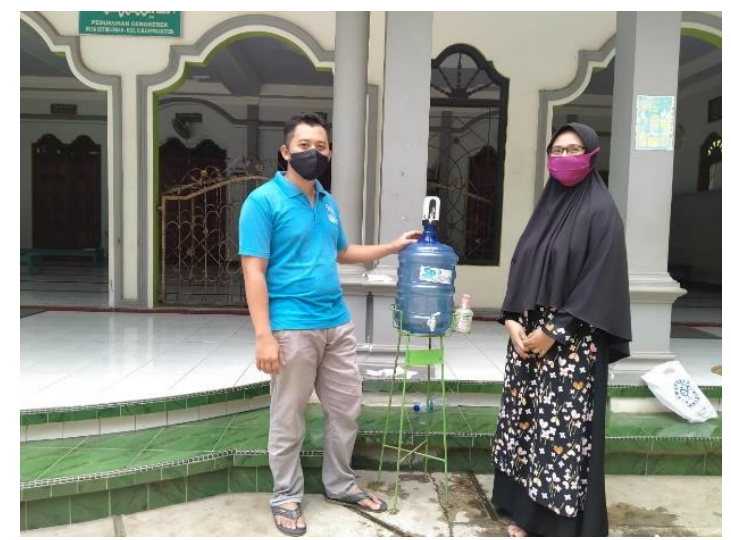

Gambar 6. Foto Penyerahan Kran Otomatis

\section{Perhitungan Pengguna}

Setelah diberikan kepada Ta'mir Masjid, kami melalukan perhitungan secara sembunyi-sembunyi lagi untuk menghitung jumlah warga yang menggunakan kran otomatis tersebut. Hasil dari perhitungan disajikan pada Tabel 4.

Tabel 4. Pengguna Kran Otomatis untuk Cuci Tangan di Masjid Jami' Al-Istiqomah

\begin{tabular}{ccc}
\hline No. & Hari ke- & Jumlah warga \\
\hline 1. & 1 & 8 \\
\hline 2. & 2 & 9 \\
\hline 3. & 3 & 11 \\
\hline 4. & 4 & 10 \\
\hline 5. & 5 & 13 \\
\hline 6. & 6 & 15 \\
\hline 7. & 7 & 14 \\
\hline
\end{tabular}

\section{Evaluasi}

Penelitian sebelumnya terdapat kran otomatis berbasis Arduino menggunakan sensor PIR (Latuconsina et al., 2017). Sensor PIR merupakan sensor infra merah juga, namun perbedaan dengan sensor proximity optic adalah sensor PIR memerlukan bahasa pemrograman untuk mengatur panjang inframerah yang harus dikeluarkan sedangkan sensor proximity optic cukup dengan memutar head timer yang berada di belakang sensor. 
Berdasarkan Tabel 3 dan Tabel 4 maka diperoleh perbandingan seperti yang disajikan pada Gambar 7.

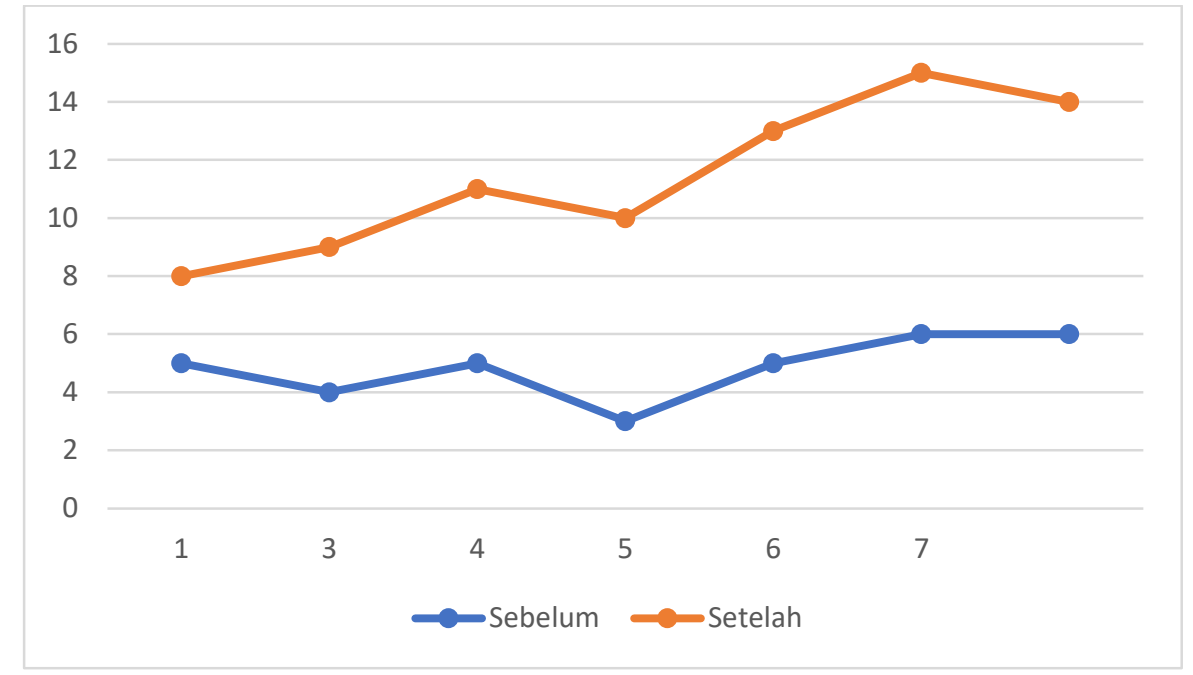

Gambar 7. Grafik Perbandingan Sebelum dan Sesudah Menggunakan Kran Otomatis Berdasarkan Gambar 7, maka jamaah lebih tertarik untuk mencuci tangan setelah menggunakan kran otomatis, sehingga diharapkan dengan adanya kran otomatis ini dapat meningkatkan budaya pola hidup bersih dan sehat (PHBS). Berdasarkan hasil wawancara, ada beberapa jamaah yang malakukan cuci tangan karena melihat jamaah lain cuci tangan.

\section{Kesimpulan}

Kesimpulan dari hasil pengabdian masyarakat adalah kran otomatis menggunakan sensor proximity optic pembuatannya lebih mudah daripada menggunakan sensor lain. Kran otomatis ini memiliki ketertarikan seseorang untuk cuci tangan. Kran otomatis memiliki ketertarikan sendiri karena bagi masyarakat warga Setrojenar, kran tersebut unik. Selain itu, banyak jamaah Masjid Jami' AlIstiqomah melakukan cuci tangan karena terpengaruh dengan jamaah lain yang sedang mencuci tangan.

\section{Ucapan Terima Kasih}

Terima kasih kepada LPPM Politeknik Dharma Patria yang telah memberikan ijin dan dukungan program pengabdian masyarkat ini. Selain itu, terima kasih kepada Ta'mir Masjid Jami' Al-Istiqomah yang telah memberikan ijin untuk dilakukan pengabdian masyarakat.

\section{Referensi}

Bahtiar, Y. A., Ariyanto, D., Taufik, M., \& Handayani, T. (2019). Pemilah Organik dengan Sensor Inframerah Terintegerasi Sensor Induktif dan Kapasitif. 13(3), 109-113. 
Beniac, D. R., Andonov, A., Grudeski, E., \& Booth, T. F. (2006). Architecture of the SARS coronavirus prefusion spike. Nature Structural and Molecular Biology, 13(8), 751-752. https://doi.org/10.1038/nsmb1123

Pencegahan Penularan Corona Virus Diseases (Covid-19) 2019 di Kabupaten Kebumen, Pub. L. No. 68, 1 (2020).

Farizi, S. Al, Harmawan, B. N., Beniac, D. R., Andonov, A., Grudeski, E., Booth, T. F., Handayani, R. T., Arradini, D., Darmayanti, A. T., Widiyanto, A., \& Atmojo, J. T. (2020). Data Transparency and Information Sharing: Coronavirus Prevention Problems in Indonesia. Nature Structural and Molecular Biology, 10(3), 751-752. https://doi.org/10.20473/jaki.v8i2.2020.35-50

Handayani, D., Hadi, D. H., Isbaniyah, F., Burhan, E., \& Agustin, H. (2020). Penyakit Virus Corona 2019. Jurnal Respirologi Indonesia, 40(2), 119-129.

Handayani, R. T., Arradini, D., Darmayanti, A. T., Widiyanto, A., \& Atmojo, J. T. (2020). Pandemi covid-19, respon imun tubuh, dan herd immunity. Jurnal Ilmiah Stikes Kendal, 10(3), 373-380.

Hartanto, S., \& Fitriyanto, R. E. (2019). Rancang Bangun Sistem Saluran Kran Air Otomatis Berbasis Arduino Atmega328P. Jurnal Ilmiah Elektrokrisna V, 7(3), 125132.

Latuconsina, R., Laisina, L. H., \& L3, A. P. (2017). Pemanfaatan Sensor PIR ( Passive Infrared Receiver ) dan Mikrokontroler Atmega 16 Untuk Efisiensi Pemakaian Air Wudhu. Jurnal Pengembangan IT (JPIT), 02(02), 18-22.

Shaputra, R., Gunoto, P., \& Irsyam, M. (2019). Kran Air Otomatis pada Tempat Berwudhu Menggunakan Sensor Ultrasonik Berbasisi Arduino Uno. 2(2), 192-201.

Susilawati, E., Yulkifli, \& Kamus, Z. (2017). Pembuatan Alat Ukur Kecepatan Putar Gear Menggunakan Sensor Proximity Induktif Dan Mikrokontroler Arduino Uno. FMIPA Universitas Negeri Padang, 10, 9-13.

Susilo, A., Rumende, C. M., Pitoyo, C. W., Santoso, W. D., Yulianti, M., Herikurniawan, H., Sinto, R., Singh, G., Nainggolan, L., Nelwan, E. J., Chen, L. K., Widhani, A., Wijaya, E., Wicaksana, B., Maksum, M., Annisa, F., Jasirwan, C. O. M., \& Yunihastuti, E. (2020). Coronavirus Disease 2019: Tinjauan Literatur Terkini. Jurnal Penyakit Dalam Indonesia, 7(1), 45. https://doi.org/10.7454/jpdi.v7i1.415

Tim BNPB Kebumen. (2020a). Kebumen Masuk Zona Orange. https://corona.kebumenkab.go.id/index.php/web/berita_detail/528

Tim BNPB Kebumen. (2020b). Kebumen Tanggap Covid-19. https://corona.kebumenkab.go.id/

Yuliana. (2020). Yuliana. Corona Virus Diseases (Covid-19) : Studi Literatur, 2(February), 124-137. https://doi.org/10.2307/j.ctvzxxb18.12 